\title{
Cellulase Enzyme Activity of Bacillus Circulans from Larvae Cossus Cossus in Lignocellulosic Substrat
}

\author{
Maswati Baharuddin ${ }^{1, ~ *, ~ A h y a r ~ A h m a d ~}{ }^{2}$, Nursiah La Nafie ${ }^{2}$, Firdaus Zenta ${ }^{2}$ \\ ${ }^{1}$ Departement of Chemistry, Islamic State of Alauddin Universty, South Sulawesi, Indonesia \\ ${ }^{2}$ Department of Chemistry, Graduate School of Science, Hasanuddin University, Makassar, South Sulawesi, Indonesia
}

Email address:

bmaswati@gmail.com (M. Baharuddin), ahyarahmad@gmail.com (A. Ahmad), lanafie@lycos.com (N. L. Nafie)

${ }^{*}$ Corresponding author

\section{To cite this article:}

Maswati Baharuddin, Ahyar Ahmad, Nursiah La Nafie, Firdaus Zenta. Cellulase Enzyme Activity of Bacillus Circulans from Larvae Cossus Cossus in Lignocellulosic Substrat. American Journal of Biomedical and Life Sciences. Vol. 4, No. 2, 2016, pp. 21-25. doi: $10.11648 /$ j.ajbls.20160402.13

Received: February 19, 2016; Accepted: March 6, 2016; Published: March 28, 2016

\begin{abstract}
Cellulase are the enzymes hydrolyzing cellulosic biomass and are produced by the microorganism that grown over cellulosic matter. Bacterial Cellulases poses more advantage when compared to the cellulases from other sources. This study aims to determine the optimum conditions of cellulase production from the bacteria Bacillus Circulans CC2 and CC4 in comparison with isolates hydrolize rice straw. CC2 and CC4 isolated from larvae Cossus cossus. The testing to produce cellulase was done with various $\mathrm{pH}$ and temperature. The enzyme activity was tested using DNS Method. The results showed that the isolated $\mathrm{CC} 2$ and $\mathrm{CC} 4$ have the same optimum temperature of $70^{\circ} \mathrm{C}$ on condition $\mathrm{CMC} 1 \%$, medium $\mathrm{pH} 7,0 . \mathrm{Crude}$ extract cellulase isolates $\mathrm{CC} 2$ work optimally at $\mathrm{pH} 4$ while the isolates $\mathrm{CC} 4$ work at $\mathrm{pH} 7$. highest activity in the cellulase enzymes hydrolyze the substrate on cellulose powder with optimum activity at pH 4 CC4 isolates of 2.775 x 10-2 U/ mL, while the enzyme activity CC2 isolates $4.359 \times 10-2 \mathrm{U} / \mathrm{mL}$, p this occurs due to the enzymatic hydrolysis of cellulosic substrates with cellulase enzymes will outline the cellulose into glucose which is a simple form.
\end{abstract}

Keywords: Cellulace, Cossus Cossus, Rice Straw

\section{Introduction}

Bioethanol can be produced from various materials such as bagasse, straw, etc. The waste materials containing lignocellulose which are very abundant availability and is not used optimally. Utilization of lignocellulosic materials for bioethanol production can be taken into consideration because it does not compete with the need for food [2]. In agricultural wastes contain lignocellulosic that can be converted into products that have economic value as compost, feed, biofuel and as a medium for bacterial growth. Lignocellulose is consists of cellulose, hemicellulose, and lignin.

One of the obstacle in lignocellulose hydrolysis of lignocellulosic biomass is the resistance that highly resistant to hydrolysis chemistry and biology particularly in cellulose crystals that forms the new cell wall [6]. The conversion of cellulose into simple sugars requires hydrolase enzyme [11].
Estimates indicate that using of cellulase enzymes in biotechnological processes can lower processing costs up to $13 \%$ [8]. Limitations on enzymatic degradation of lignocellulosic biomass is mostly related with enzymatic stability, inhibitor, and by products [9]. Search of new enzymes with higher specific activity is one way to overcome the hydrolysis of lignocellulosic biomass. Each cellulolytic bacteria can produce different cellulase complex enzyme, depend on the gene that is owned and carbon sources used [14]. Utilization of enzyme-producing bacteria as chosen because it has several advantages such as: low production costs, production time is relatively short, has grown and speed easily controlled. Recent evidence suggests that insects life in the trees produces lignocellulose as food [15] in Willis et al., 2010.

The ability of insects such as Cossus cossus [4] are capable of crushing lignocellulose into sugar that is affected by microbial symbionts are capable of producing cellulase enzyme [3]. Some insects has evolved using lignocellulosic 
substrates as a food source, thus becoming one of the alternatives are good resources to generate new cellulolytic enzymes [16]. Larvae Cossus cossus is one insect that is able to produce enzyme cellulase. This is because the process of life using the tree as a place to live and its food. These larvae has characteristics that reflect their way of life, drill on wood and trunk. Big head, longer and wider with large jaw. Prothorax shaped like a typical plate or shield that has a tail smooth margin [10].

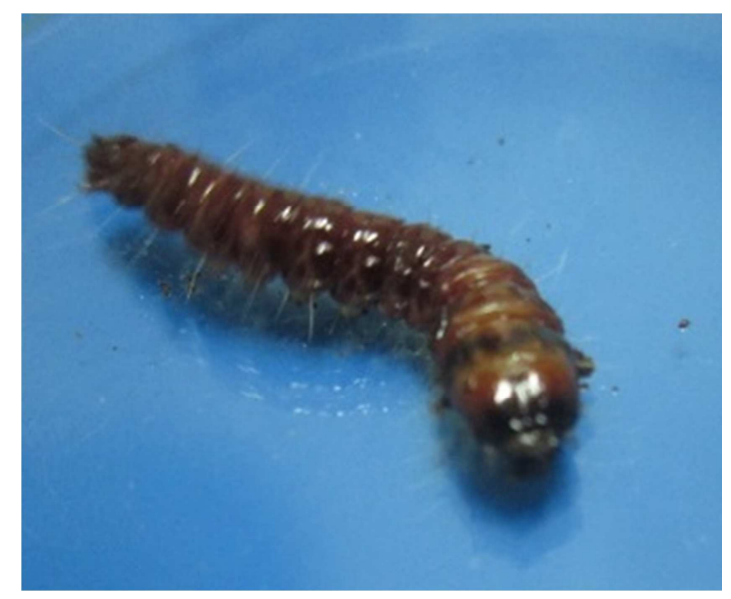

Figure 1. Cossus cossus larvae.

Based on the above, then do research about potential of cellulase enzymes [4] from bacteria larvae Cossus cossus in hydrolysis of rice straw.

\section{Methods}

\subsection{Bacterial Isolation}

Larva Cossus cossus were collected from Lejja South Sulawesi for isolation of cellulase-producing Bacteria. The cellulace Producing microorganisms showed the zone of clearance on this agar.

\subsection{Identification of Cellulolytic-Producing Bacteria}

The selected isolates were identified to the genus level using morphological and Biochemical methods. Pure bacterial cultures were obtained and the nucleotide sequence of the 16S rRNA gene of isolated bacteria was amplified by PCR employing DNA Polimerase.

\subsection{Isolation of Lignocellulose and Cellulose from Rice Straw}

Isolation of lignocellulose and cellulose from rice straw Isolation of a straw lignocellulose is done by first drying the straw to be used up to a size of 40 mesh. Rice straw that had been sifted and then washed with distilled water. The mixture was filtered, the next residue is dried in an oven at a temperature of $50^{\circ} \mathrm{C}$. After that, added $\mathrm{HCl} 3 \%$ to dissolve the minerals contained in rice straw. Then filtered, and the residue is washed with distilled water until $\mathrm{pH}$ neutral (test with litmus), and then dried in an oven. As for isolation of cellulose is done by adding solution of $\mathrm{NaOCl} 10 \%$ to lignocellulose powder, and then macerate for 24 hours. Then the mixture is filtered and the sediment was washed with distilled water until $\mathrm{pH}$ neutral (test with litmus), dried in oven and weighed weight. For the next, determination of lignin content of lignocellulose and cellulose from rice straw using methods [19].

\subsection{Production of Cellulase Enzyme}

Cellulolytic bacterial isolates were inoculated as much as 2 os in $200 \mathrm{ml}$ of CMC Broth media $1 \%$ ( $1 \mathrm{~g}$ of CMC, $0.1 \mathrm{~g}$ $\mathrm{K}_{2} \mathrm{HPO}_{4}, \mathrm{CaCl}_{2} .2 \mathrm{H}_{2} \mathrm{O} 0.04 \mathrm{~g}, 0.04$ grams of $\mathrm{MgSO}_{4} .7 \mathrm{H}_{2} \mathrm{O}$, yeast extract $0.4 \mathrm{~g}$ ) were incubated on incubator shaker at temperature of $50^{\circ} \mathrm{C}$ until the exponential phase. And the next, crude enzyme that obtained in the centrifugation at $3,000 \mathrm{rpm}$ for 15 minutes at a temperature of $4^{\circ} \mathrm{C}$.

Effect $\mathrm{pH}$ On Cellulase Production

The Effect of optimum $\mathrm{pH}$ For Cellulaase production by the experimental microorganisms was determined by culturing the bacteria in the producton media with different $\mathrm{pH}$. The experiment was carried out individually at various $\mathrm{pH}$ such as $3,4,5,6,7,8,9$. The enzyme assay was carried aut idividually after 72 hours of incubated $37^{\circ} \mathrm{C}$ [17]

Effect of temperature on Cellulase Production

The ffect of temperature on cellulase production was studied by incubating the culture media at various temperatures such as $20,30,40,50,60,70,80$, and $90^{\circ} \mathrm{C}$.

Assay Of Cellulase

The activity of Cellulase was assayed using DNS Method. The DNS Assay was carried out as $0,2 \mathrm{ml}$ of culture filtrate was mixed with $1 \% \mathrm{CMC}$ in a test tube and incubated at $40^{\circ} \mathrm{C}$ for 30 minutes. The reaction was terminated by adding $3 \mathrm{ml}$ of DNS reagen. The tube was then incubated at $100^{\circ} \mathrm{C}$. One unit of the cellulase activity refers to the amount of enzyme that release $1 \mu \mathrm{M}$ glucose [5].

\subsection{Cellulase Activity on Substrate Rice Straw}

Lignocellulosic substrates 0.05 grams, cellulose and straw powder are added $5 \mathrm{ml}$ of buffer and $5 \mathrm{ml}$ of crude extract enzyme. The reaction between substrate and crude extract enzyme is done in erlemeyer $100 \mathrm{ml}$ for 60 minutes at optimum temperature. After that, the reaction is stopped.

\section{Results and Discussion}

\subsection{Isolation and Identification of the Isolated Bacterial Strain}

Four strains of cellulose-hydrolitic bacteria were isolated from larvae Cossus cossus and designeted as strain CC1-4. All strains grew well at $35^{\circ} \mathrm{C}$. The fragment comarising of $16 \mathrm{~S} r$ RNA gene were also determined for novel isolates. The nearly full leghy sequences were obtained by PCR, coned and sequenced. All sequences showed $>89 \%$ identity wit $16 \mathrm{~S}$ rRNA gene of a previosly analyzed Bacillus circulans strain CC2. as well as a high identities of amino acid sequence of 16S r RNA gene from Bacillus circulans was also detected. 


\subsection{Determination of Lignin Content Lignocelluloses and Cellulose from Rice Straw}

Based on the determination of lignin content that performed [18], obtained percentate of lignocellulose in the rice straw is $22.8698 \%$ while the content of cellulose in straw is $31.9813 \%$. Straw has a crude fiber content which high enough, based on research [13] about the analysis of crude fiber in rice straw, showed that inside the straw there is a $57.04 \%$ crude fiber.

Based on the determination of lignin content of lignocellulose, cellulose and lignin in the straw powder using method SNI, obtained lignocelluloses content in rice straw is $22.8698 \%$, this result approaching lignocellulose content in rice straw based on chemical composition of raw materials the stimulation of the production of ethanol are $23 \%$ while in rice straw cellulose content obtained at $31.9813 \%$, while based on the chemical composition of raw materials and the stimulation of ethanol sellulose production in rice straw is $32 \%$.

In the determination of lignin content is obtained lignin content of $12.2788 \%$. This result is very low when compared with the results of the research who did [13], who get the lignin content in rice straw is $32.07 \%$, but the results of this research approaches the lignin content which based on the chemical composition of raw materials and stimulation ethanol production is $13 \%$. This content shows amount of lignin levels that exist in rice straw so that lignin removal should be done, because lignin inhibits hydrolysis process of cellulose. High lignin content minimizes enzyme access to substrates that causing low activity of enzymes in hydrolyzing substrate.

\subsection{Effect Temperature on Cellulase Activity}

The main parameters like temperature, $\mathrm{pH}$ are very essential parameters of the cellulase production. To Optimaze the optimum temperature for the better cellulase production, production were made in various temperatures. The higher cellulase activity was found as $19,41 \times 10^{-4} \mathrm{U} / \mathrm{mL} \mathrm{CC} 2$ isolate and $20,34 \times 10^{-4} \mathrm{U} / \mathrm{mL}$ at $70^{\circ} \mathrm{C}$ isolate $\mathrm{CC} 4$ (Fig. 1). The temperature requirement of the organisms is based on the nature of organisms. A Work done by Abdelnasser and Ahmed in was found to optimum temperature for Bacillus $\mathrm{sp}$ at $75^{\circ} \mathrm{C}$ [9].

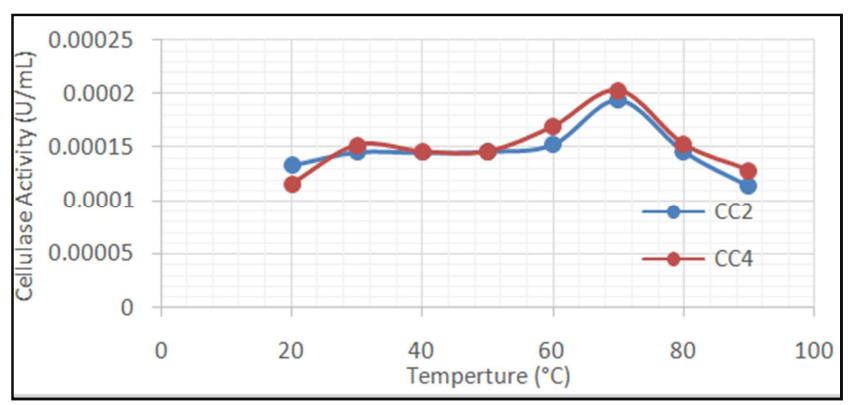

Figure 2. Effect the temperature on the activity of Cellulase of isolate CC2 and CC4 conditions: Substrate CMC 1\% and pH 7 phospate Buffer.

\subsection{Effect pH on Cellulase Activity}

As the $\mathrm{pH}$ is found to be also impotent enviromental parameters, varying $\mathrm{pH}$ on Cellulase production. Maximum prodoction of the enzym $15,88 \times 10^{-4}$ isolate $\mathrm{CC} 2$ was obtaened at the $\mathrm{pH} 4$ and $15,40 \times 10^{-4} \mathrm{U} / \mathrm{mL}$ isolate $\mathrm{CC} 4$ at the $\mathrm{pH} 7$ as shown in (Fig. 2). The enzym has abroad range of $\mathrm{pH}$ activity (1-11) with optimal $\mathrm{pH}$ at 7 whic is close the optimum $\mathrm{pH}$ value of most Bacillus Anoxybacillus Flavithermus EHPI [9]

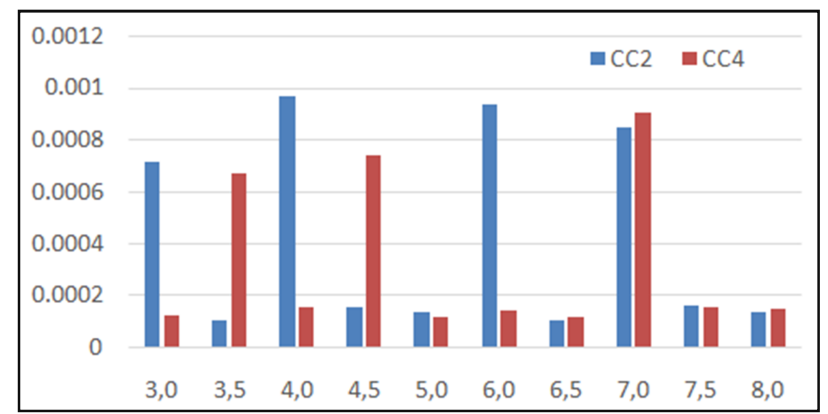

Figure 3. Effect of $\mathrm{pH}$ on the activity of Cellulase of isolate CC2 and CC4 conditions: Substrate CMC 1\%.

\subsection{Hydrolysis of Lignocellulose, Cellulose and Straw Powder}

Based on substrate hydrolysis (lignocellulose powder, cellulose powder, and powders straw) is used Isolate CC2 and $\mathrm{CC} 4$ at $\mathrm{pH} 7.5$ and 4 (based on testing $\mathrm{pH}$ optimum) (Fig. 2) [3] enzyme activity obtained at $\lambda \max =545$ are as follows.

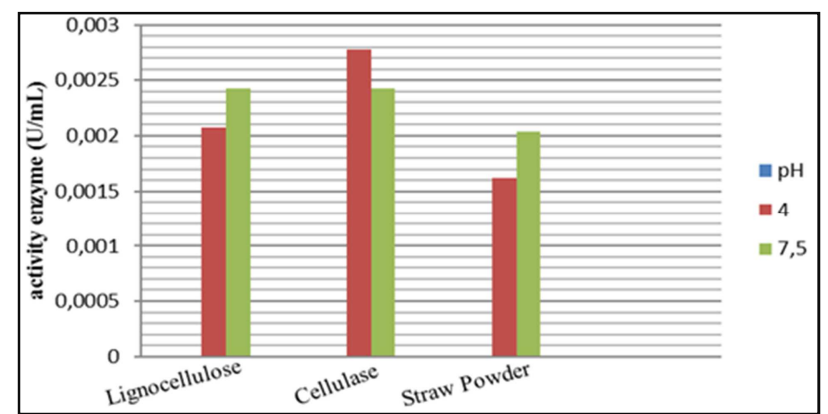

Figure 4. The Results of hydrolysis substrate using cellulase enzyme from Isolates CC4 at pH 7.5 and 4.

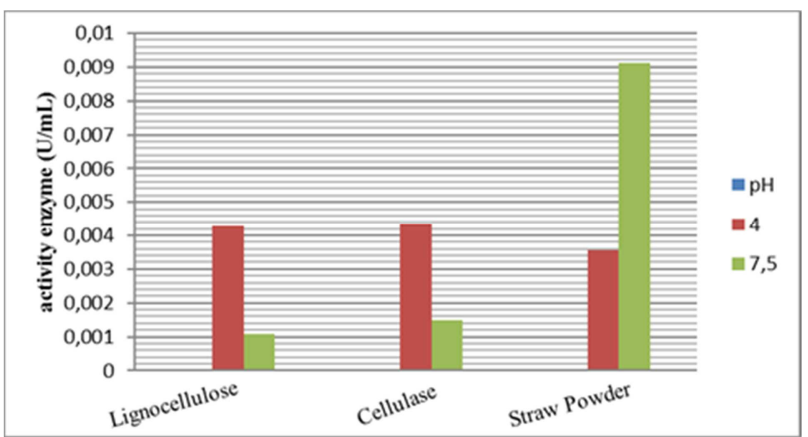

Figure 5. The Results of hydrolysis substrate using a cellulase enzyme from Isolates $\mathrm{CC} 2$ at $\mathrm{pH} 7.5$ and 4. 
Enzyme activity is caused also on the temperatures used. In this research is used temperature of $50^{\circ} \mathrm{C}$ as the optimum temperature to determine the highest activity of cellulase enzymes in hydrolyzing substrate.

The using optimum temperature is used to optimize the work of cellulase enzymes. It means that when the enzyme is on temperature above $50^{\circ} \mathrm{C}$ will be damaged (denatured), but when the enzyme is on temperature below $50^{\circ} \mathrm{C}$, the enzyme is not active [20].

Based on the research that has been done, get the best activity in cellulase enzymes in hydrolysis substrate (straw powder, lignocellulose powder and cellulose powder) which is on a substrate of cellulose powder. This is seen in the activity of the enzyme after measured by UV-VIS Spectrophotometer, to Isolate CC4 has the highest activity on cellulose of $4.359 \times 10^{-2} \mathrm{U} / \mathrm{mL}$ as well as on isolate CC2 has activity $2.425 \times 10^{-2} \mathrm{U} / \mathrm{mL}$, it is caused the enzyme used is cellulase enzyme which is an enzyme that can hydrolyze cellulose. And cellulose used is pure cellulose.

Beside that, the substrate lignocellulosic powder obtained enzyme activity CC4 isolates of $4.295 \times 10^{-2} \mathrm{U} / \mathrm{mL}$ and the lignocellulose powder $\mathrm{CC} 2$ isolates ie $2.07 \times 10^{-2} \mathrm{U} / \mathrm{mL}$. When compared to isolates straw powder CC4 $3.57 \times 10$ ${ }^{2} \mathrm{U} / \mathrm{mL}$ and to isolate CC2 $1.61 \times 10^{-2}$. The amount enzyme activity of the lignocellulosic compared to the straw powder is caused by lignocellulosic substrates have undergone removal of minerals so partly can be hydrolyzed by the enzyme cellulose. On lignocellulose and straw powder had lower enzyme activity, it is because on the second substrate portion forming component in the form of cellulose and lignin. Where, lignin cellulose binding cellulose physically so that preventing the cellulase enzyme to work up to hydrolysis in substrate [12].

The type of strain, culture condition, nature of substrat and availaibility of nutriens are the othe important factoreffecting yield of enzyme production.

\section{Conclusion}

Bacillus Circulans isolated in his study offer a good prospect for Cellulolytic enzyme production and this method can be applied as a part of bioethanol process using lignocellulsic matrials example rice straw. For application Lignocellulose isolation process of rice straw can be carried out using hydrochloric acid $(\mathrm{HCl})$ and found $20.2 \%$ of lignocellulose contents.

The isolation process of cellulose from rice straw is carrioed by using a solution of sodium hypochlorite $(\mathrm{NaOCl})$ $10 \%$ and obtained the cellulose content is $32 \%$.

Hydrolysis of the substrate by using a crude extract of enzyme at $\mathrm{pH}$ and temperature optimum yield the highest activity on cellulose. On the cellulose powder with optimum activity at $\mathrm{pH} 4$ on $\mathrm{CC} 4$ isolate of $2,775 \times 10-2 \mathrm{U} / \mathrm{mL}$ while on $\mathrm{CC} 2$ isolate the enzyme activity of $4.359 \times 10-2 \mathrm{U} / \mathrm{mL}$, this is because the hydrolysis that occurs enzymaticly on a substrate of cellulose with cellulase enzymes will decipher cellulose into simple shapes that glucose.

\section{Acknowledgement}

The author thank for Mr. Abdul Rauf Patong for any guidance, motivation and assistance in research, may Allah reward.

\section{References}

[1] Delalibera, I., Jo H., and Kenneth F. R. 2005. Contrast In Cellulolytic of Gut Mikcroorganisms Between The Wood Borer, Saperda vestita (Coleoptera: Cerambiydae), and The Bark Beetles, Ips pini and Dendroctonus frontalis (Coleoptera: Curculionidae). Physiological Ecologhy Entomol 34(3): 541547.

[2] Anindyawati, Trisanti. "Prospek Enzim Dan Limbah Lignoselulosa Untuk Produksi Bioetanol". Pusat Penelitian Bioteknologi-LIPI, 2009.

[3] Baharuddin, M., Patong, R., Ahmad, A., La Nafie, N., 2014. Pengaruh Suhu dan $\mathrm{pH}$ terhadap hidrolisis $\mathrm{CMC}$ oleh enzim selulase dari isolat bakteri larva Cossus cossus. J Teknosasins dan Teknologi 8(3): 343-356.

[4] Baharuddin, M., Patong, R., Ahmad, A., La Nafie, N., 2014. Isolasi dan Karakterisasi Bakteri Simbion Larva Kupu-kupu Cossus cossus Penghasil Selulase. Al-Kimia Jurnal Penelitian sains Kimia 2(2).

[5] Bai, S., M. Ravi K., D. J. Mukesh K.,. Balashanmugan., M. D. Balakumaran., P. T. Kalaicchevlan. 2012. Cellulase Production by Bacillus subtilis Isolatd from Cow Dung. Archives of Applied Science Research, 4(1): 269-279.

[6] Chandel, A., and Sigh O. V. 2011. Weedy Lignocellulosic feedstock and Microbial metabolic engineering: advancing the generation of Biofuel. Appl Microbiol Biotechnol 89: 12891303.

[7] Abdelnasser, S. S., Ahmed I., 2007. Isolation and Identificatio of New Cellulases Producing Thermophilic Bacteria From an Eghyptian Hot Spring and some Properties of Crude enzyme. Australian J. of Basic and Applied Science, 1(4): 473-478.

[8] Lynd, L. R., Willem P. J., Willem H. V. Z., and Isak S. P. 2002. Microbial Cellulose Utilization: Fundamental and Biotechnology. Microbiology and Molecular Biology Reviews, 66(3) 506-577.

[9] Willis, J. D., Cris O., and Juan L. J. 2010. Methods for Discovery and Characterization of Cellulolytic Enzymes from Insects, Journal compilation, Insect Science 17: 184-198.

[10] Lawrence, J. F., and Britton E. B. 1991. The Insects of Australian. A text Book for Student and Research Worker. Vol. 2. Cornell Universty Press Ithaca: New York.

[11] Kalluri, U. C., and Keller M. 2012. Bioenergy Research: A New Paradigm in Multidiciplinary research. Review J. The Royal Society Interface 7. 1391-1401.

[12] Meryandini, Anja., 2009. Isolasi Bakteri Selulolitik dan Karakterisasi Enzimnya, Makara sains 13(1) 2009 h 36.

[13] Larasati, Raissa. "Sintesis Fase Diam Selulosa-g-AAM Dengan Berbagai Kadar Penaut-Silang Sebagai Media Separator Xantorizol Dari Ekstrak Temu Lawak". Skripsi. Bogor: Departeman Kimia Fakultas Matematika dan Ilmu Pengetahuan Alam IPB, 2012. 
[14] Vilanova, C., Marco G., Laura D., Salvador G., Vicente S., Esther B., Daniel R., Manuel P. 2012. Bacteria from acidic to strongly alkaline insect midguts: Potensial sources of extreme cellulolytic enzymes. Biomass \& Bioenergy 45: 288-294.

[15] Geib, S. M., Filley, T. R., Hatcher, P. G., Hoover, K., Carlson, J. E., Jimenez-Gasco Mdel, M., Nakagawa-Izumi, A., Sleighter, R. L. and Tien, M. 2008. Lignin degradation in wood-feeding insects. Proceedings of the National Academy of Sciences 105: 12932-12937.

[16] Purwadaria, T., Marbun, P. A., Arnold P. S., Pius P. K. 2003. Perbandingan Aktivitas Enzim Selulase dari Bakteri dan Kapang Hasil Isolasi dari Rayap. 8(4): 213-219.
[17] Shakar, T., Isairastu L., Cellulase production by Bacillus pumilus EWBCMI under Varying Cultural Conditions. Middle-East J. Sci. Res., 8(1): 40-45, 2011.

[18] Standar Nasional Indonesia. "Cara Uji Kadar Lignin 04922008”. Badan Standar Nasional, 2008.

[19] Standar Nasional Indonesia. "Cara Uji Kadar Selulosa, $\alpha$ selulosa, $\beta$-selulosa dan $\gamma$-selulosa 0444-2009”. Badan Standar Nasional, 2009.

[20] Irfan, M., Safdar A., Quratuain S., Muhammad N. 2012. Isolation and Screening of Cellulolytic Bacteria from Soil and Optimization of Cellulase Production and Activity. Journal of Biochemistry 37(3): 287-293. 